\title{
The Effects of Perceived Stress and Facebook on Accounting Students' Academic Performance
}

\author{
Helen G. Gabre \\ Assistant Professor of Accounting, Alabama A\&M University \\ 4900 Meridian Street North, Normal, AL 35762, USA
}

Tel: 1-256-372-4785Ｅ-mail: helen.gabre@aamu.edu

Gaurav Kumar (Corresponding author)

Associate Professor of Accounting

University of Arkansas at Little Rock

2801 S University Ave, Little Rock, AR 72204, USA

Tel: 1-501-569-3051Ｆax: 1-501-683-7021Ｅ-mail: gkumar@ualr.edu

Received: September 6, 2012

Accepted: September 22, $2012 \quad$ Online Published: September 25, 2012

doi:10.5430/afr.v1n2p87

URL: http://dx.doi.org/10.5430/afr.v1n2p87

\begin{abstract}
This paper has three objectives. First, we investigate the effects of perceived stress on the academic performance of accounting students. Second, we examine the association of Facebook use with perceived stress. Third, we investigate the effect of Facebook usage on accounting students' academic performance. To measure the perceived stress we used the Perceived Stress Scale developed in the prior research for the shorter version and used it to collect data from accounting students at two universities. We found that female accounting students reported higher stress scores than their male counterparts. In addition, the results indicated that this phenomenon affected their academic performance negatively. African American accounting students were more likely to report higher stress scores than their non-African American counterparts. Further investigation showed that African American students are more likely to live alone or to live in the dorm. They are also more likely to be working while going to school. Our analysis shows that higher Facebook use is associated with stress and the respondents in our sample, who used Facebook while studying, reported higher levels of stress and were less in control of things. Finally, our results show that accounting students who use Facebook while studying experienced lower academic performance after controlling for stress.
\end{abstract}

Keywords: Perceived stress, Academic performance, Accounting students, Facebook

\section{Introduction}

It is undeniable that academic engagements can be one of the most financially rewarding activities for many college graduates. By the same token, these engagements can create different type of stressful circumstances for the participants (Aldwin \& Greenberger, 1987; Bonner \& Rich, 1987, 1988; Cope \& Hannah, 1975 as cited by Nonis, Hudson, Logan \& Ford, 1998; Priester \& Clum, 1993; Rawson, Bloomer \& Kendall, 1994; Schotte \& Clum, 1982). In addition, different stressful circumstances can negatively impact the probability of succeeding in these academic endeavors. Therefore, the study of the mental status of students is very important since it may affect the likelihood of completing college. According to Szulecka, Springett, and de Pauw (1987), "the major causes of attrition in first year college student are emotional rather than academic factors" (as cited in Pritchard \&Wilson, 2003, p. 18).

Several studies have examined the effect of perceived stress on academic performance (Lloyd, Alexander, Rice \& Greenfield, 1980; Pritchard \&Wilson, 2003; Sandler, 2001; Wintre \& Yaffe, 2000). Stress studies on health-care related students seem to dominate the landscape of academic stress research. The literature is replete with stress studies involving medical, pharmacology, dental as well as nursing students (Dunn, Iglewicz \& Moutier, 2008; Dyrbye, Thomas \& Shanafelt, 2006; Gupchup, Borrego, \& Konduri, 2004; Mosley, Perrin, Neral, Dubbert, Grothues, \& Pinto, 1994; Murphy, Gray, Sterling, Reeves \& DuCette, 2008; Sanders \& Lushington, 2002). There are a few articles on the effect of stress-related issues on academic achievement of business students (for example, Trine \& 
Schellenger, 1999). However, the impact of perceived stress on accounting students' academic performance has not been investigated. Accounting has been recognized as a top major in terms of job opportunities, and the number of students majoring in accounting has been increasing over the last few years (AICPA) (Note 1). Anecdotal evidence suggests, however, that the attrition rate in accounting majors has been increasing significantly as well. Therefore, the first objective of this research is to examine the possible relationship of perceived stress on accounting students' Grade Point Average (GPA).

The present college student body is rightfully dubbed as Generation Y or the Millennial Generation. This is the generation that is born between "the second half of the 1970s and the first half of the 1990s" (Yan, 2006). Generation $\mathrm{Y}$ has a high-techno culture that affects its information processing procedures immensely. It has unprecedented access to information through the different social media outlets. The advent of Facebook, Twitter, YouTube and different blogs, to name a few, has revolutionized the concept of communication entirely.

Even though there are many advantages to this unique digital culture, there have been concerns regarding college students' electronic media use and academic performance. The results of different studies in this area have been mixed. While many researchers (Kirschner \& Karphinski, 2010; O’Dell, 2011; Stollak, Vandenberg, Burklund \& Weiss, 2011) find that there is a negative relationship between excessive use of social media and academic performance, others (Belnora, 2009) suggest that there is no negative association between academic achievement and use of these outlets. Therefore, the second objective of this paper is to examine the relationship between accounting students' GPA and multitasking viaexcessive use of social media. Since Facebook is used by $96 \%$ of college students (O’Dell, 2011), the social media of choice for this study is Facebook.

Many studies argue that Facebook participation promotes social support and connectedness (O'Dell, 2011). However, O'Dell (2011) states that “...students might actually end up feeling more depressed or lonely". Since this study is examining the perceived stress of accounting students, we will also investigate the possible association of Facebook usage and perceived stress.

The unique contributions of this study to the extant body of literature are manifold. First, we extend the present stress research to the accounting education domain. Second, this paper investigates the association of Facebook with perceived stress. We are not aware of any study conducted on accounting students' academic performance and use of social media. Therefore, an examination of the effect of Facebook usage on accounting students' academic performance is conducted. The next section provides a literature review and develops research hypotheses. The third section provides a discussion on research methodology and data collection. The next section provides descriptive analyses, tests the research hypotheses, and presents the results and the last section concludes the paper.

\section{Literature Review}

The negative consequences of stress have been the subject matter of many health-related discussions. In addition, many academic studies have investigated its effect on academic performance.Even though the effect of stress on a person's health has been affirmed repeatedly by the medical community, the studies about the role that stress plays in impacting academic performance have mixed results.Pritchard and Wilson (2003) studied the effect of emotional health on GPA and retention. The results suggest that emotional health as measured by 55 stressors i.e. conflicts with professors, dissatisfaction with school etc. were significantly associated with GPA and retention. In addition, Sandler (2001) studied the effect of perceived stress on several endogenous variables e.g. institutional commitment, academic performance, goal commitment, and intent to persist, to name a few. He found that perceived stress had significant total effect on many endogenous variables, in general, and on academic performance, in particular. Likewise, Lloyd, Alexander, Rice and Greefield (1980) found that stressful life event changes affected academic performance negatively. Wintre and Yaffe (2000) examined first-year students' adjustment to university life and found that students exhibited lower GPA with increases in stress levels (as cited in Friedlander, Reid, Shupak \& Cribbie, 2007, p. 260). Additionally, Friedlander et al. (2007) performed a longitudinal study of first-year university undergraduate students. The results suggested that as perceived stress decreased, academic as well as personal-emotional adjustments improved.

On the other hand, Sanders and Lushington (2002) examined the effect of stress on dental students' academic performance. Based on the responses from the Dental Environment Stress (DES) questionnaire, they did not find a strong relationship between stress and academic performance. Trine and Schellenger (1999) investigated several determinant factors i.e. GPA, financial accounting and finance grades, motivation, stress etc., on performancein upper level corporate finance class. While motivation had a significant effect on performance, other psychological factors such as stress did not exhibit a significant impact on performance. 
Even though the above studies examined the effects of stress on academic performance, none of them involved an examination of perceived stress on accounting students' academic performance. Therefore, this paper extends the extant research into the accounting education domain. However, since there is insufficient theory to support any relation between stress and academic performance, the following hypothesis is posited in null form:

$H 1_{0}$ : There is no significant association between accounting students' perceived stress scores and academic performance.

One of the most interesting aspects of stress research has been the results associated with gender issues. Prior research indicates that females have a higher likelihood of suffering from anxiety, depression and stress. Gupchup, Borrego, and Konduri (2004) investigated doctor of pharmacy students and their health-related qualities. They examined the possible association of gender with student's life stress. They found that female students have higher student life stress scores than their male counterparts. Women are also found to report symptoms of depression and anxiety in response to stress whereas men under stress just increased their activity level (Zucherman, 1989 as cited in Goldman \&Wong, 1997, p. 605). Additionally, Cassady and Johnson (2001) investigated the role of cognitive test anxiety on academic performance.Interestingly, females "reported higher level of text anxiety both emotional and cognitive test anxiety" (p. 290). Several papers (Bandalos, Yates \& Thorndike-Christ, 1995; Hembree, 1988; Volkmer \& Feather, 1991; Zeidner, 1990) have conducted stress-related research and found that female subjects reported higher level of anxiety than male subjects. Again, none of the above studies include accounting majors. Therefore, we postulate the following hypotheses in this study:

H2(a): Female accounting students are more likely to report a higher level of perceived stress than male accounting students.

H2(b): Female accounting students with higher level of perceived stress are more likely to have a lower academic performance than male accounting students with higher levels of perceived stress.

\subsection{Social Support or Stress?}

It is undeniable that social media, especially Facebook, has become the venue of communication for college students of today. "The Higher Education Research Institute (HERI, 2007) reported that $94 \%$ offirst year college students use social networking websites, and data from a survey by Mastrodicasa and Kepic (2005) showed that $85 \%$ ofstudents at a large research university had accounts on Facebook, the most popular social networking site" (Junco, Heiberger \& Loken, 2010).

Prior studies have investigated different factors that augment or moderate stress in individuals. One of the factors that isbelieved to have a moderating effect on stress is social support. For example, parental social support is believed to be associated to academic achievement in a college setting (Curtona, Cole, Colangelo, Assouline, \& Russell, 1994 as cited in DeBerard, Spielmans \& Julka, 2004). Similarly, DeBerard et al., (2004) investigated predictors of academic achievement. They found that perceived social support from family, friends and significant others was "a useful way of insulating the individual from the harmful impact of stress". Additionally, Chambel and Curral (2005) found that there was a significant negative relationship between anxiety/depression and peer support among undergraduate students.

Due to the recent phenomenal advancement in technology, college students of today use the electronic social media as an avenue of social support. Bond-Fraser, Fraser, Korotkov and Claybourn (2011) describe Generation Y (most college students), “...techno-literate, visual learners who like to be connected and expect immediate feedback". O'Dell (2011) statedthat "social media-using students are twice as likely as other students to feel well-liked by their peers and to participant in extracurricular activities. And 20\% more of Facebook-using students (as compared to students who didn't use Facebook) said they felt connected to their school and community". However, the research on emotional effect of Facebook has mixed results.For example, O’Dell (2011) reports that students who use Facebook may feel depressed or lonely.According to, Dr. Gwenn O'Keeffe, a Boston-area pediatrician,the plausible argument for this phenomenon could bethat the constant pictorial barrage of happy people telling their tales may make students sad and depressed "if they think they don't measure up" (as cited in Tanner, 2011). In fact, other researchers have found that large number of contacts and largeamount of usage time can trigger stress (Popular Facebook users). Dr. CathyCharles of Edinburgh Napier University, who led a team to study the effects of Facebook, explains the results as follows:

We found it was actually those with the most contacts, those who had invested the most time in the site, who were the ones most likely to be stressed. It is like being a mini news channel about yourself. The more 
people you have the more you feel there is an audience there. You are almost a mini celebrity and the bigger

the audience the more pressure your feel to produce something about yourself. (Popular Facebook users...) Since accounting students, as part of the Y generation, are involved in the new hype of social media, it is imperative to investigate the role of Facebook in augmenting their stress.

Therefore, we postulate the following hypothesis:

H3:There is an association between Facebook usage and reported perceived stress scores.

Additionally, the effect of Facebook usage on academic performance has been a topic of concern for educators. Just as the emotional studies on Facebook usage have varied results, studies on Facebook's effect on academic performance are not consistent either. Several studies have demonstrated its negative effect on academic achievement due to multitasking. O'Dell (2011) reports that multitasking students earned 20\% lower grades compared to students who did not multitask. Stollak, Vandenberg, Burklund and Weiss (2011) investigated whether participating in social media by students affect their academic performance. While they did not find a statistically significant difference between the different social media (Facebook, YouTube, Twitter etc.), the results demonstrated that students with higher GPAs spent significantly lower time on YouTube and Facebook than students with lower GPAs.

In addition, Kirschner and Karphinski (2010) investigated the relationship of Facebook usage and GPA and hours of study. The results suggest that students who use Facebook had lower GPA and studied fewer hours per week. Similarly, Junco (2011) demonstrates that there is a negative relationship between Facebook use and Facebook activities and student engagement defined as "the amount of physical and psychological energy that the student devotes to the academic experience" (Astin, 1984 as cited in Junco, 2011, p. 163). There was also a negative relationship between Facebook use and Facebook activities and time spent preparing for class (Junco, 2011).

Even though the above studies demonstrate the negative effect of Facebook usage on academic performance, other researchers have casted doubt on this claim. Studies by Northwestern University and University of New Hampshire have concluded that there was not significant connection between social media usage and academic performance (Belnora, 2009 and BrainTrack, 2010). Alternatively, Austin and Totaro (2011) argue that while excessive Internet usage negatively affects the likelihood of earning high grade, moderate usage may, in fact, help achieve top grade. There is also an implied scenario, which signifies that it may be the multitasking and not just the usage of social media that is the culprit for lower academic performance by college students. Watters (2011) reports a study by Professors Rey Junco and Sheila Cotton in which multitasking between studying and Facebook surfing is associated with lower GPA.

In this study, we examine the role of Facebook usage on academic performance. The choice of Facebook is deliberate.First, with 96\% of college students using Facebook (O'Dell, 2011), it is the social media of choice for the college generation. This phenomenon of huge number of users is not by accident. Facebook's perceived enjoyment, perceived ease of use, and perceived usefulness has been the major catalyst for this high-tech usage explosion (Suki, Ramayah \& Ly, 2011).Second, according to Kirschner and Karpinski (2010) "[f]acebook remains primarily a college-age and emerging adult phenomenon"

(p. 1239).

Therefore, based on the aforementioned studies, we posit the following hypotheses:

H4a:Accounting students who use Facebook excessively (Note 2) are more likely to havea lower GPA than accounting students who use Facebook moderately (Note 3).

H4b:Accounting students who multitask Facebook with studying/doing homework are more likely to have lower GPA than accounting students who do not multitask.

\section{Methodology}

The purpose of this study is to examine the impact of perceived stress on accounting students' academic performance. The rationale to measuring the perception rather than the objective event has been effectively argued by Varni, Katz, Colegrove and Dolgin (1994) since "the meaning derived from the stressful event, not necessarily the event itself, may result in the perception of the event as being stressful" (as cited by Goldman \& Wong, 1997, p. 604). Additionally, Colbert (2009) defines stress reaction as "[h]ow our mind and body react to an environment that is largely shaped by our perceptions of an event, person, or situation" (p. 5).

Hence, this study will employ the Perceived Stress Scale (PSS) developed by Cohen, Kamarck and Mermelstein (1983) and Cohen and Williamson (1988) for the shorter version (APPENDIX A). The PSS was developed with 14 items (PSS14), 10 items (PSS10) and 4 items (PSS4) with Cronbach's alpha coefficient for internal reliability scores 
of .75, .78 and .60, respectively (Cohen et al., 1983 and Cohen \& Williamson,1988). We adopta modified PSS10 for our study since it has a higher internal consistency score of .78 (Perceived Stress Scale).

We collect theoverall GPA scores of the accounting students directly from the Registrars of the schools involved in this study.We believe this objective collection of data will strengthen the reliability of the information compared to self-reported academic performance. Kay and Stevens (2011) hypothesized that students who spent more time on Facebook would have lower GPA than students who spent less time on the social media. However, the results suggested a positive relationship between time spent on Facebook and GPA. We believe that one of the reasons for this puzzling result could be the unreliability of the self-reported GPA scores. To measure the academic performance of accounting students, we collected the overall GPA of students and ranked it systematically i.e. a GPA of 4.0 is ranked 1, a GPA of 3.9 is ranked 2 and so on.

Hypotheses H4a states that excessive Facebook usage may result in lower GPA scores. Based on a study by University of New Hampshire about the relationship between social networking and grades, we define light use of Facebook as usage fewer than 30 minutes per day and heavy usage as usage exceeding 60 minutes per day (Belnora, 2009). In addition, Facebook-related questions of 14 and 15 in our instrument (presented in APPENDIX A) were the modified versions of questions adopted from Junco and Cotten (2011).

\section{Results}

As mentioned previously, we employed the Perceived Stress Scale (PSS) developed by Cohenet al. (1983) and Cohen and Williamson (1988) for the shorter version. Therefore, we asked students to self-report if they experienced stress in the last semester. We used a five-point Likert-scale where the responses ranged from Never (0) to Very Often (4). In addition to the data on stress, we asked questions on demographic information such as gender, age, marital status, race, academic status etc.

We distributed 120 instruments and collected 95completed instruments from students. These students were recruited out of two universitieslocated in the south one of which is an HBCU (Historically Black College), and the other is a metropolitan university with mostly commuter population. The Institutional Review Boards at both these colleges approved this study. All the data was collected in the spring semester of 2012. These instruments were handed out in classes, and participants were asked to complete the questionnaire after obtaining informed consent. It took about 15 minutes to complete the instrument and the participants were not given any extra credit for taking part in the study. In order to maintain confidentiality, only participant numbers were placed on the instruments.

Out of the 95 participants, there were 56 females and 39 males. Forty-seven percent of the respondents were Caucasian, $40 \%$ were African-American, $6 \%$ were Asian, $3 \%$ were Hispanic, and the rest were classified as "Other". A large majority of students in our sample (65) were 20-29 years old and 23 students were 30-39 years old. While $66 \%$ of our sample is comprised of seniors, $28 \%$ are juniors, and the rest are sophomores. There were no freshmen in our study. Seventy-eight students reported that they worked while attending college. Out of this number, 37 worked full-time and 41 worked part-time. These numbers are a fair representation of the total student population at the twoinstitutions. Consistent with O'Dell (2011), 93\% of the students in our sample reported that they have a Facebook presence. Out of this percentage, 70\% surf Facebook for less than 30 minutes, 20\% surf for between 30 and 60 minutes and $10 \%$ surf for more than 60 minutes. Hence, only a small number of students (eight) were identified in the "heavy usage" group as defined by the study of the University of New Hampshire (Belnora, 2009).

\subsection{Hypotheses Testing}

Our first hypothesis states that there is a significant association between accounting students' perceived stress score and academic performance. To test this hypothesis, we ran a Principal Component Analysis on the 10 stress indicators in our instrument. Table 1 provides the results of this analysis. This table shows that the six stress variables (upset, unable to control, nervous, unable to cope, angry, and high difficulties) loaded on Factor 1 and therefore, we have named that factor Stressful and the other four variables in our instrument (confident, things going my way, control irritations and feel on top of things) loaded on Factor 2 and therefore, we have named this factor In

Control. These two factors combined explained $60.96 \%$ of the variance.In order to measure sample adequacy for factor analysis, the Kaiser-Meyer-Olkin(KMO) test was used resulting in $\mathrm{KMO}=0.852$.The results for Bartlett's Test of sphericity $\chi 2(45)=390.372, \mathrm{p}<.0001$ confirms that the correlation between variables is large enough for principal components analysis.In addition, Cronbach's Alpha for both factors were 0.862 for factor 1 i.e. Stressful and 0.798 for factor 2 i.e. In Control, respectively. 
A regression analysis was conducted with GPA as a dependent variable (ranked overall GPA) and the two variables (Stressful and In Control) as independent variables. The results were not statistically significant. Therefore, we were unable to reject the null hypothesis in $\mathrm{H}_{0}$.

Our second hypothesis is stated in two parts. Part a of this hypothesis states that female accounting students are more likely to report a higher level of perceived stress than male accounting students. To test this hypothesis, we ran an independent samples t-test on the six stress items that loaded on the first factor in the Principal Component Analysis. The results (in Table 2) show that gender is significant for the following variables (Unable to Control, Unable to cope and High difficulties). Therefore, this result shows that female accounting students were unable to control important things in their life, unable to cope with the work, and faced high difficulties in their previous semester. These results provide support for Hypothesis 2(a). Part b of the second hypothesis states that female accounting students with higher level of perceived stress are more likely to have a lower academic performance than male accounting students with higher level of perceived stress. Table 3 provides the results of regression analysis with ranked GPA as a dependent variable and the above factors (Stressful and In Control) and gender as independent variables. The results show that female accounting students that have reported higher stress scores ranked lower than male accounting students on their GPA (marginally significant). Therefore, this provides evidence to support Hypothesis 2(b). Interestingly, male accounting students reported that they felt more confident $(p=.029)$ than their female counterparts.

Since $40 \%$ of the students are African-Americans, we performed an independent samples t-test to compare the means of stress scores reported across races. The results demonstrated a statistically significant result for high difficulties ( $p$ $=0.034)$. In other words, African-American accounting students reported that they faced high difficulties while pursuing their education. However, when we conducted a regression analysis by race to examine the role of stress on academic performance, no statistically significant result was observed.

In order to capture the reasons for the higher stress scores by African Americans, we conducted a t-statistics on factors that may induce stress i.e. living conditions, work/school commitments etc. There are significant results for living with family $(\mathrm{p}=.01)$ and marital status $(\mathrm{p}=.007)$. There are also marginally significant results for living in the dorm $(\mathrm{p}=.083)$, living alone $(\mathrm{p}=.06)$ and for working during school $(\mathrm{p}=.06)$. An examination of the means revealed that significantly more African American accounting students live in a dorm or live alone than their non-African American counterparts. More Caucasian accounting students were married or reported that they lived with family. This intuitive result is not surprising since living alone precludes the moderating effect of family support. Solberg and Villarreal (1997) studied Hispanic college students and found the moderating effects of [family] social support and self-efficacy between stress and physical and psychological distress. Even though living in a dorm affords a better social contact, it may not provide an equivalent amount of social support as living with a family. Trine and Schellenger (1999) affirm that "sharing living accommodation with others (beyond the family)" affected finance students' academic performance in a negative manner. In addition, more African American students reported juggling work and school responsibilities simultaneously which can result in a stressful mental state.

The third hypothesis states that there is an association between Facebook usage and reported perceived stress scores. To test this hypothesis, we ran a regression analysis on Stressful, the factor scoreson stress variables from the Principal Component Analysis, as a dependent variable and the three Facebook attributes. The three Facebook attributes are: Facebook presence (FACEBOOK), using Facebook while doing schoolwork (FACESCHOOL), and using Facebook while studying (FACESTUDY). The results of this analysis are presented in Table 4. The results show that there is a positive association between stress scores and multitasking with Facebook while studying or FACESTUDY (marginally significant at $\mathrm{p}=0.059$ ).

The fourth hypothesis is stated in two parts. Part a of this hypothesis states that accounting students who use Facebook excessively are more likely to have a lower GPA than accounting students who use Facebook moderately. However, the descriptive analysis showed that only $10 \%$ of our sample used Facebook excessively. Therefore, the results of this analysis were not significant. Part $b$ of this hypothesis states that accounting students who multitask Facebook with studying/doing homework are more likely to have lower GPA than accounting students who do not multitask. Table 5 presents the results of this analysisi.e. that the students who use Facebook while studying have lower academic performance (marginally significant). Therefore, this result provides evidence to support Hypothesis 4(b).

\section{Discussion of Results}

Various studies have examined the effect of stress on academic performance. However, none of those studies have specifically examined the effect of stress on accounting students' academic performance. This research has three 
objectives. First, we investigate the effects of perceived stress on the academic performance of accounting students. Second, we examine the association of Facebook use with perceived stress. Third, weinvestigate the effect of Facebook usage on accounting students' academic performance. To measure the perceived stress, the Perceived Stress Scale (PSS) developed by Cohen et al. (1983) and Cohen and Williamson (1988) was used to collect data from accounting students at two universities. Next, Principal Component Analysis was applied on the ten stress items to extract two factors (Stressful and In Control). We did not find a significant relationship between perceived stress and academic performance of accounting students. One of the reasons for this result could be that the relationship between perceived stress and performance is curvilinear, that is "people will perform best under moderate amounts of stress" (Noniset al., 1998, p. 600).

However, we found that female accounting students reported higher stress scores than their male counterparts. In addition, the results indicated that this phenomenon affected their academic performance negatively. This result is very interesting in light of the fact that the undergraduate accounting student population has been dominated by highnumber of female enrollment (Nelson \& Vendrzyk, 1996). Accounting departments and university counseling service offices must be aware of this phenomenon. University counseling personnel should communicate the different stress minimization and stress reducing activities to female accounting students. In addition, future research on the possible coping capabilities of female accounting students is warranted.

Moreover, African American accounting students were more likely to report higher stress scores (in the area of reporting high difficulties) than their non-African American counterparts. This result is consistent with the extant literature on the issue. There have been stress-related studies involving African American students. Baldwin, Chambliss, and Towler (2003) examined African-American college students and the role of life events stress. The results suggested that African American upperclassmen reported high-level academic stress.

Further investigation on the cause for significant high difficulties report by African-American accounting students showed that African American students are more likely to live alone or to live in the dorm. They are also more likely to be working while going to school.This result has serious implications in terms of minority representation in the profession.

There has been a legitimate concern about retention and attrition rate of minority students in universities in the United States (U.S.). According to Nettles, and Gosman (1986) and Wilson (1994), African American students are more likely to drop out of college than their nonminority counterparts (as cited in Baldwin et al., 2003). Additionally, Cross (1993) states that "historically black colleges tend to have a highly disappointing student graduation rate" (as cited in Baldwin et al., 2003). It is evident that poor academic performance leads to student attrition.

Therefore, educational institutions, especially HBCUs (Historically Black Colleges and Universities) whose student population is predominantly African American should emphasize stress-reducing activities. Providing Wellness Center scholarships and creating teacher-student mentorship programs for social support can serve as a catalyst towards establishing a suitable environment for learning. In addition, accounting departments in HBCUs must make a concerted effort to network with the business community of the local area in order to facilitate paid internship opportunities which will enhance professional competency while alleviating the financial burden of participants. Since there has been no research on African American accounting students in relation to stress and performance, this paper contributes to the body of knowledge about the role of perceived stress on African American accounting majors' academic performance.

The analysis ofthe second objective shows that students who used Facebookwhile studyingreported higher levels of stress and were less in control of things. This result is not surprising. Multitasking with Facebook during studying can interfere witha student's ability to concentrate on and comprehend the study material. Therefore, based on anecdotal evidence, it is intuitive to surmise that accounting students get stressed if they feel that they do not comprehend the subject matter properly. This leads to the second result of this study i.e. accounting students who use Facebook while studying experienced lower academic performance after controlling for stress. This is an important contribution of this study. O'Dell (2011) reports that 96\% of college students use Facebook. This statistic combined with our results has significant repercussions for the academia. Advisors, guidance counselors and accounting professors should take a vigilant stand in making students aware of the outcome of this common distractive activity. Another approach would be to take advantage of this technology and use it to benefit students in achieving their academic goal. Accounting professors can use Facebook as an alternative teaching tool using different creative methods. If it seems impractical to discourage accounting students from spending too much time on social networks such as Facebook, it might as well be expedient to use these avenues for advancing accounting education. Enhancing 
a pedagogical use of Facebook technology in accounting education can divert its distractive effect into an educational engagement.

\subsection{Limitations and Suggestions for Future Research}

As with all research, our paper has some limitations. Although our sample size meets the minimum thresholds for the statistical analysis, it is still small. However, it was a conscious decision to physically collect data from participants as opposed to setting up an online questionnaire that could have given us a larger sample. The decision to collect data personally enabled the authors to gather as much complete responses as possible. A second limitation of our paper is that a larger portion of our sample (90\%) falls under "moderate" usage of Facebook (less than 60 minutes per day). Finally, it is likely that inferior academic performance in the past is affecting the current performance, instead of high stress. This can be examined in future research. Future research can also examine these objectives with a broader sample with an equal distribution of these responses so that the effects of "high" versus "moderate" usage of Facebook can be compared. On the other hand, we overcome a limitation of prior research by objectively gathering the respondents' GPA from the respective Registrars instead of using self-report responses. In spite of these limitations, this is an important topic for accounting education research and our results provide important contribution to this literature.

\section{References}

Aldwin, C., \& Greenberger, E. (1987). Cultural differences in the predictors of depressions. American Journal of Community Psychology, 15(4), 789-813. http://dx.doi.org/10.1007/BF00919803

Austin, W., \& Totaro, M. W. (2011). High school students' academic performance and Internet usage. Journal of Economics and Economic Education Research, 12(1), 41-54.

Baldwin, D. R., Chambliss, L. N., \& Towler, K. (2003). Optimism and stress: An African-American college student perspective. College Student Journal, 37 (2), 276-285.

Bandalos, D. L., Yates, K., \& Thorndike-Christ, T. (1995). Effects of math self-concept, perceived self-efficacy, and attributions for failure and success on test anxiety. Journal of Educational Psychology, 87, 611-623. http://dx.doi.org/10.1037/0022-0663.87.4.611

Belnora, L. (2009, December 23). Social networking doesn't harm student performance. The Kansas Free

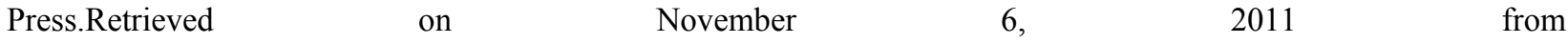
http://www.kansasfreepress.com/2009/12/social-networking-doesnt-harm-student-performance.html

Bond-Fraser, L., Fraser I., Korotkov D., \& Claybourn, M. (2011). The changing face of law schools: The impact of Generation Y. Perspectives, 14.Retrieved in fall, 2011 from http://aabss.org/Perspectives2011/IanFraserGENYLawschool.pdf

Bonner, R. L., \& Rich, A. R. (1987). Towardpredictive model of suicidal ideation and behavior: Some preliminary data in college students. Suicide and Life-Threatening Behavior, 17(1), 50-63.

Bonner, R. L., \& Rich, A. R. (1988). A prospective investigation of suicidal ideation in college students: A test of a model. Suicide and Life Threatening Behavior, 18(3), 245-258.

BrainTrack. (2010). Study says social networking does not affect GPA. Retrieved on November 6, 2011 from http://www.braintrack.com/college-and-work-news/articles/study-says-social-networking-does-not-affect-gpa-10071 601

Cassady, J. C., \& Johnson, R. E. (2001). Cognitive test anxiety and academic performance. Contemporary Educational Psychology, 27, 270-295. http://dx.doi.org/10.1006/ceps.2001.1094

Chambel, M. J., \& Curral, L. (2005). Stress in academic life: Work characteristics as predictors of student well-being and performance. Applied Psychology: An International Review, 54(1), 135-147. http://dx.doi.org/10.1111/j.1464-0597.2005.00200.x

Cohen S., Kamarck, T., \& Mermelstein, R. (1983). A global measure of perceived stress. Journal of Health and Social Behavior, 24, 385-396. http://dx.doi.org/10.2307/2136404

Cohen, S., \& Williamson, G. (1988). Perceived stress in a probability sample of the United States. In Spacapan, S., \& Oskamp, S. (Eds.). The social psychology of health. Thousand Oaks, CA: Sage Publications, 31-67.

Colbert, B. J. (2009). Navigating your future: An interactive journey to personal and academic success. New Jersey: Pearson Prentice Hall. 
Cope, R. G. \& Hannah, W. (1975). Revolving College Doors: The Causes and consequences of Dropping Out, Stopping Out, and Transferring. New York: John Wiley \& Sons.

Cross, T. L. (1993). The myth that preferential college admissions create high black student dropout rates. Journal of Blacks in Higher Education, 1, 71-74. http://dx.doi.org/10.2307/2962516

DeBerard, M. S., Spielmans, G. I., \& Julka, D. L. (2004). Predictors of academic achievement and retention among college freshmen: a longitudinal study. College Student Journal, 38(1), 66-80.

Dunn, L. G., Iglewicz, A., \& Moutier, C. (2008). A conceptual model of medical student well-being: Promoting resilience and preventing burnout. Academic Psychiatry, 32, 44-53. http://dx.doi.org/10.1176/appi.ap.32.1.44

Dyrbye, L. N., Thomas, M. F., \& Shanafelt, T. D. (2006). Systematic review of depression, anxiety, and other indicators of psychological distress among U.S. and Canadian medical students. Academic Medicine, 81(4), 354-373. http://dx.doi.org/10.1097/00001888-200604000-00009

Friedlander, L. J., Reid, G. J., Shupak, N., \& Cribbie, R. (2007). Social support, self-esteem, and stress as predictors of adjustment to university among first-year undergraduates. Journal of College Student Development, 48(3), 259-274. http://dx.doi.org/10.1353/csd.2007.0024

Goldman, C. S., \& Wong, E. H. (1997). Stress and the college student. Education, 117(4), 604-611.

Gupchup G. V., Borrego, M. E., \& Konduri, N. (2004). The impact of student life stress on health related quality of life among doctor of pharmacy students. College Student Journal, 38(2), 292-301.

Hembree, R. (1988). Correlates, causes, and treatment of test anxiety. Review of Educational Research, 58, 47-77.

Junco, R. (2011). The relationship between frequency of Facebook use, participation in Facebook activities and student engagement. Compute \& Education, 58, 162- 171. http://dx.doi.org/10.1016/j.compedu.2011.08.004

Junco, R. \& Cotten, S. (2011). A decade of distraction? How multitasking affects student outcomes. A Decade in Internet Time Symposium on the Dynamics of the internet and Society, Oxford, UK, September 22, 2011. http://dx.doi.org/10.2139/ssrn.1927049

Junco, R., Heiberger. G. \& Loken, E. (2011). The effect of Twitter on college studentengagement and grades. Journal of Computer Assisted Learning, 27(2), 119-132. http://dx.doi.org/10.1111/j.1365-2729.2010.00387.x

Kay, K., \& Stevens, C. (2011). Effects of Facebook use on academic achievement. Retrieved on November 6, 2011 from http://www.comm50.com/mctheorywiki/index.php?

Kirschner, P. A., \& Karphinski, A. C. (2010). Facebook and academic performance. Computers in Human Behavior, 26(6), 1237-1245. http://dx.doi.org/10.1016/j.chb.2010.03.024

Lloyd, C., Alexander, A. A., Rice, D. G., \& Greefield, N. S. (1980). Life events as predictors of academic performance. Journal of Human stress, 6(3), 15-25. http://dx.doi.org/10.1080/0097840X.1980.9936094

Mosley, T. H., Perrin, S. G., Neral, S. M., Dubbert, P. M., Grothues, C. A., \& Pinto, B. M. (1994). Stress, coping and well-being among third-year medical student. Academic Medicine, 69(9), 765-767. http://dx.doi.org/10.1097/00001888-199409000-00024

Murphy, R. J., Gray, S. A., Sterling, G., Reeves, K., \& DuCette, J. (2008). A comparative study of professional student stress. Journal of Dental Education, 73(3), 328-337.

Nelson, I. T. \& Vendrzyk, V. P. (1996). Trends in Accounting Student Characteristics:A Longitudinal Study at FSA Schools, 1991-1995. Journal of Accounting Education, 453-475. http://dx.doi.org/10.1016/S0748-5751(97)80001-7

Nettles, M. T., Thoeny, A. R., \& Gosman, E. J. (1986). Comparative and predictive analyses of black and white students' college achievement and experiences. Journal of Higher Education, 57, 289-318. http://dx.doi.org/10.2307/1981554

Nonis, S.A., Hudson, G.I., Logan, L.B., and Ford, C.W. (1998). Influence of perceived control over time on college students' stress and stress-related outcomes. Research in Higher Education, 39 (5), 587-605. http://dx.doi.org/10.1023/A:1018753706925

O'Dell, J. (2011). For students, what is the Facebook effect on grades? Retrieved on November 6, 2011 from http://mashable.com/2011/04/27/facebook-effect-students/

$\begin{array}{llllll}\text { Perceived } & \text { Stress } & \text { Scale. } & \text { Retrieved } & \text { in } & \text { fall, }\end{array}$ http://www.ncsu.edu/assessment/resources/perceived_stress_scale.pdf 
Popular Facebook Users 'fee more stress'. (2011). The Telegraph. Retrieved in spring, 2011 from http://www.telegraph.co.uk/technology/facebook/8330544/Popular-Facebook-users-feel-more-stress.html

Priester, M. \& Clum G. A. (1993). Perceived problem-solving ability as a predictor of depression, hopelessness, and suicide ideation in college population. Journal of Counseling Psychology, 40(1), 79-85. http://dx.doi.org/10.1037/0022-0167.40.1.79

Pritchard, M.E., \& Wilson, G. S. (2003). Using Emotional and Social Factors to Predict Student Success. Journal of College Student Development, 44(1), 18-28. http://dx.doi.org/10.1353/csd.2003.0008

Rawson, H. E., Bloomer, K., \& Kendall, A. (1994). Stress, anxiety, depression, and physical illness in college students. The Journal of Genetic Psychology, 155(3), 321-330. http://dx.doi.org/10.1080/00221325.1994.9914782

Sanders, A. E., \& Lushington, K. (2002). Effect of perceived stress on student performance in dental school. Journal of Dental Education, 66(1), 75-81.

Sandler, M. (2001). Perceived stress and an elaborated structural model of adult student persistence: An examination of financial aid, financial satisfaction, intent to persist and persistence.Retrieved on November 5, 2011 from http://www.eric.ed.gov/PDFS/ED452361.pdf

Schotte, D. E., \& Clum, G. A. (1982). Suicide ideation in college population:A test of a model. Journal of Counseling and Clinical Psychology, 50(5), 690-696. http://dx.doi.org/10.1037/0022-006X.50.5.690

Solberg, V. S. \& Villarreal, P. (1997). Examination of self-efficacy, social support, and stress as predictors of psychological and physical distress among Hispanic college students. HispanicJournal of Behavioral Sciences, 19, 182-201. http://dx.doi.org/10.1177/07399863970192006

Stollak, M. J., Vandenberg, A., Burklund, A., \& Weiss, S. (2011). Getting social: The impact of social networking usage on grades among college students. Proceedings from ASBBS Annual Conference (pp. 859-865). Retrieved on February November 6, 20111 from http://www.asbbs.org/files/2011/ASBBS2011v1/PDF/S/StollakM.pdf

Suki, N. M., Ramayah, T., \& Ly, K. K. (2011). Empirical investigation on factors influencing the behavioral intention to use Facebook. Universal Access in the Information Society. Retrieved on November 6, 2011 from http://www.springerlink.com/content/fut0582147801354/

Tanner, L. (2011, March 28). Docs Warn About Facebook Use And Teen Depression. The Huffington Post. Retrieved from http://www.huffingtonpost.com/2011/03/28/facebook-depression-2011_n_841282.html

Trine, J. A., \& Schellenger, M. H. (1999). Determinants of student performance in an upper level corporate finance course. Academy of Educational Leadership Journal, 3(2), 42-52.

Varni, J., Katz, E., Colegrove, R., \& Dolgin, M. (1994). Perceived stress and adjustment of long-term survivors of childhood cancer. Journal of Psychosocial Oncology, 12(3), 1-16. http://dx.doi.org/10.1300/J077V12N03_01

Volkmer, R. E., \& Feather, N. T. (1991). Relations between Type A scores, internallocus of control and test anxiety. Personality and Individual Differences, 12, 205-209. http://dx.doi.org/10.1016/0191-8869(91)90104-J

Watters, A. (2011, September 19). Texting and facebooking while studying related to lower GPA. Hack Education. Retrieved on $\quad$ November $\quad 6, \quad 2011$ from http://www.hackeducation.com/2011/09/19/texting-and-facebooking-while-studying-related-to-lower-gpa/

Wilson, R. (1994). The participation of African Americans in American higher education.In M. J. Justiz et al. (Eds.), Minorities in Higher education, Phoenix: Oryx Press.

Wintre, M. G., \& Yafe, M. (2000). First-year students' adjustment to university life as a function of relationships with parents. Journal of Adolescent Research, 15(1), 9-37. http://dx.doi.org/10.1177/0743558400151002

Yan, S. (2006, December 8). Understanding Generation Y.The Oberlin Review. Retrieved in spring, 2012 from http://www.oberlin.edu/stupub/ocreview/2006/12/08/features/Understanding_Generation_Y.html

Zeidner, M. (1990). Does test anxiety bias scholastic aptitude test performance by gender and sociocultural group? Journal of Personality Assessment, 55, 145-160. 
Table 1. Principal Component Analysis

This table presents the results of factor loadings for component analysis on the ten stress indicators in the instrument.

\begin{tabular}{|l|c|c|}
\hline Variables in Instrument & Component 1 (Stressful) & Component 2 (In Control) \\
\hline Upset & 0.742 & \\
\hline Unable to Control & 0.679 & \\
\hline Nervous & 0.752 & 0.762 \\
\hline Confident & & 0.708 \\
\hline Things Going My Way & 0.702 & 0.816 \\
\hline Unable to Cope & & 0.744 \\
\hline Control Irritations & & \\
\hline On Top of Things & 0.708 & \\
\hline Angry & 0.835 & \\
\hline High Difficulties & & \\
\hline
\end{tabular}

Table 2. Independent Samples t-Test on Gender

This table provides the results of independent samples t-test on gender

\begin{tabular}{|c|c|c|c|c|}
\hline Variable & Gender & N & Mean & p-value \\
\hline \multirow{2}{*}{ Upset } & $\mathrm{M}$ & 39 & 2.3077 & 0.073 \\
\cline { 2 - 4 } & $\mathrm{F}$ & 56 & 2.6964 & \\
\hline Unable to Control & $\mathrm{M}$ & 39 & 2.000 & \multirow{2}{*}{$\mathbf{0 . 0 4 8}$} \\
\cline { 2 - 4 } & $\mathrm{F}$ & 56 & 2.4821 & \\
\hline Nervous & $\mathrm{M}$ & 39 & 2.8205 & \multirow{2}{*}{0.154} \\
\cline { 2 - 4 } & $\mathrm{F}$ & 56 & 3.1250 & \\
\hline Unable to Cope & $\mathrm{M}$ & 39 & 1.5897 & \multirow{2}{*}{$\mathbf{0 . 0 0 0}$} \\
\cline { 2 - 4 } & $\mathrm{F}$ & 56 & 2.5714 & \\
\hline \multirow{2}{*}{ Angry } & $\mathrm{M}$ & 39 & 2.1538 & \multirow{2}{*}{0.381} \\
\cline { 2 - 4 } & $\mathrm{F}$ & 56 & 2.3571 & \\
\hline High Difficulties & $\mathrm{M}$ & 39 & 1.9487 & \multirow{2}{*}{$\mathbf{0 . 0 1 5}$} \\
\cline { 2 - 4 } & $\mathrm{F}$ & 56 & 2.5714 & \\
\hline
\end{tabular}

Table 3. Regression Results on Gender and Academic Performance

This table presents the results of regression analysis with Ranked GPA as dependent variable and stress scores and gender as independent variables.

\begin{tabular}{|c|c|c|c|}
\hline & Std. Beta & t & p-value \\
\hline Intercept & 36.414 & 5.481 & 0.000 \\
\hline Stressful & 3.304 & 1.696 & $\mathbf{0 . 0 9 3}$ \\
\hline In Control & -0.282 & -0.146 & 0.884 \\
\hline Gender & -4.406 & -1.099 & 0.275 \\
\hline
\end{tabular}


Table 4. Regression Results on Facebook and Stress Scores

This table presents the results of regression analysis with Stressful (from Table 1) as dependent variable and the three Facebook attributes as independent variables.

\begin{tabular}{|l|l|l|l|}
\hline & Std. Beta & $\mathbf{t}$ & p-value \\
\hline Intercept & -0.005 & -0.009 & 0.993 \\
\hline FACESTUDY & 0.333 & 1.912 & $\mathbf{0 . 0 5 9}$ \\
\hline FACESCHOOL & -0.200 & -1.137 & 0.259 \\
\hline FACEBOOK & -0.065 & -0.596 & 0.552 \\
\hline
\end{tabular}

Table 5. Regression Results on Facebook with Study and Academic Performance

This table presents the results of regression analysis with Ranked GPA as dependent variable and stress scores and Facebook use as independent variables.

\begin{tabular}{|l|l|l|l|}
\hline & Std. Beta & t & p-value \\
\hline Intercept & 36.028 & 8.615 & 0.000 \\
\hline Stressful & 3.423 & 1.794 & $\mathbf{0 . 0 7 6}$ \\
\hline In Control & -0.587 & -0.306 & 0.760 \\
\hline FACESTUDY & -3.309 & -1.768 & $\mathbf{0 . 0 8 0}$ \\
\hline
\end{tabular}

APPENDIX A

The questions in this scale ask you about your feelings and thoughts during the last semester. In each case, you will be asked to indicate by circling how often you felt or thought a certain way.

\section{0 $=$ Never $1=$ Almost Never $\mathbf{2}=$ Sometimes $3=$ Fairly Often $4=$ Very Often}

1. In the last semester, how often have you been upset because of something that happened unexpectedly?

2. In the last semester, how often have you felt that you were unable to control the important things in your life?

3. In the last semester, how often have you felt nervous and

"stressed"? 01234

4. In the last semester, how often have you felt confident about your ability to handle your personal problems? 01234

5. In the last semester, how often have you felt that things were going your way?

6. In the last semester, how often have you found that you could Not cope with all the things that you had to do? 01234 
7. In the last semester, how often have you been able to control irritations in your life?.

8. In the last semester, how often have you felt that you were

on top of things?

9. In the last semester, how often have you been angered because of things that were outside of your control?

10. In the last semester, how often have you felt difficulties were piling up so high that you could not overcome them?

\section{DEMOGRAPHIC DATA}

\section{STUDENT ID}

1. GENDER: Male Female

2. AGE: $20-29$ 30-39 $40-49$ $50-59$ $60+$

3. MARITAL STATUS: Married Single

4. RACE ( ) Caucasian

( ) African American

( ) Black (non-Hispanic)

() Hispanic

( ) Native American

( ) Asian

( ) Other, please specify

5. ACADEMICSTATUS: ( ) Senior
( ) Junior
( ) Sophmore
( ) Freshman

5. Do you have dependent children? Yes No

If yes, number of dependent children

6. My living arrangement is

YES NO

a. I live with my family

b. I live in the dorm 
c. I live in an apartment by myself

d. I live in an apartment with a roommate

7. Do you work while going to school?

a. Full time

b. Part time

8. Are you a member of University Greek organizations?

9. Are you a member of University Honor society?

10. Are you an athlete?

11. Do you work out in the gym?

12. Do you have a Facebook presence?

13. How often do you do schoolwork at the same time you are visiting Facebook?

Never Rarely Sometimes Somewhat frequently Very Frequently

$\begin{array}{lllll}1 & 2 & 3 & 4 & 5\end{array}$

14. How often do you do study at the same time you are visiting Facebook?

Never Rarely Sometimes Somewhat frequently Very Frequently

$\begin{array}{lllll}1 & 2 & 3 & 4 & 5\end{array}$

\section{I surf Facebook for}

a. Less than 30 minutes per day.

b. Between 30 and 60 minutes per day.

c. More than 60 minutes per day.

Note 1. http://www.aicpa.org/Career/SalaryInfo/Pages/default.aspx

Note 2. We define excessive use of Facebook as usage more than 60 minutes per day (Belnora, 2009).

Note 3. We define moderate use of Facebook as usage between 30 to 60 minutes per day Belnora, 2009). 